\title{
TAMBANG PASIR DAN DAMPAK SOSIAL EKONOMI MASYARAKAT DI PESISIR PANTAI
}

\author{
Dewi Anggariani, Santri Sahar, M. Syaiful* \\ Dosen Sosiologi Agama, Universitas Islam Negeri Alauddin Makassar \\ *Email Korespondensi: muhammad.sayful@uin-alauddin.ac.id
}

\begin{abstract}
Abstrak. Secara umum, pembangunan infrastruktur dimaksudkan untuk lebih meningkatkan kesejahteraan bagi masyarakat. Namun apabila mengabaikan aspek studi kelayakan dan analisis dampak lingkungan, maka akan berpotensi menciptakan kerusakan ekologi maupun ekonomi dan sosial budaya masyarakat setempat. Oleh karena itu, penelitian ini bertujuan untuk mengetahui landasan kebijakan, juga untuk mengetahui dampak sosial dan ekonomi dari keberadaan tambang pasir terhadap masyarakat Galesong. Penelitian ini menggunakan bentuk studi mikro demografi atau biasa disebut quasi anthropological. Penelitian ini dilakukan di wilayah pesisir pantai Galesong. Analisis data dalam penelitian ini dilakukan secara kualitatif. Hasil penelitian menunjukkan bahwa aktivitas penambangan pasir di wilayah pesisir pantai Galesong dimulai pada Tahun 2017 sehingga belum mengacu pada Perda Sulsel No. 2 Tahun 2019, dimana sebagai acuan untuk mengeluarkan izin lokasi dan izin pengelolaan pertambangan pasir di Sulawesi Selatan. Adapun dampak dari aktivitas penambangan pasir terhadap kondisi sosial ekonomi masyarakat di wilayah pesisir pantai Galesong, antara lain hilangnya wilayah penangkapan ikan akibat pengerukan pasir laut, menyebabkan air menjadi keruh. Selain itu, terjadi perubahan sosial ekonomi, dimana para nelayan kecil harus meninggalkan aktifitasnya dan bergabung dengan para nelayan penangkap ikan di laut dalam dan menjadi sawi pada punggawa perahu-perahu besar. Dampak selanjutnya adalah adanya patroli polisi laut yang membuat para nelayan merasa tertekan dan tidak lagi memiliki kebebasan untuk melaut seperti dulu kala. Dengan dasar kesimpulan tersebut, diharapkan Pemerintah Daerah membuat model kebijakan dalam pengelolaan aktivitas penambangan pasir di wilayah pesisir pantai Galesong. Jika tidak, cepat atau lambat masalahnya akan semakin membesar.
\end{abstract}

Kata Kunci:

Dampak Ekonomi;

Dampak Sosial;

Kebijakan;

Nelayan;

Tambang Pasir.

artikel dengan akses terbuka dibawah lisensi CC BY -4.0 


\section{PENDAHULUAN}

Pembangunan jalan, jembatan, pelabuhan, dan infrastruktur lainnya membawa manfaat bagi aktivitas ekonomi karena memberikan akses produksi dan distribusi barang dan jasa untuk melayani konsumsi masyarakat (S. Sartono, 2019). Demikian pula dengan reklamasi pantai untuk pengembangan pusat industri dan pemukiman (Ismar $\mathrm{Hi}$ Garuan \& S. Suranto, 2016). Akibatnya terjadi peningkatan kebutuhan material berupa pasir untuk penimbunan. Lain halnya dengan aktivitas penambangan pasir di wilayah pesisir pantai Galesong, Kabupaten Takalar, untuk menimbun kawasan Centre Point of Indonesia (CPI) dan New Port Makassar (NPM). Namun, aktivitas penambangan pasir ini telah memberikan dampak sosial ekonomi bagi masyarakat sekitar.

Sebagaimana berdasarkan Pasal 33 ayat (3) Undang-Undang Dasar Negara Republik Indonesia Tahun 1945 (selanjutnya disebut UUD NRI Tahun 1945), mengatur bahwa:

"Bumi dan air dan kekayaan alam yang terkandung di dalamnya dikuasai oleh negara dan dipergunakan untuk sebesar-besar kemakmuran rakyat."

Berdasarkan Pasal 33 ayat (4) UUD NRI Tahun 1945, mengatur bahwa:

"Perekonomian nasional diselenggarakan berdasar atas demokrasi ekonomi dengan prinsip kebersamaan, efisiensi berkeadilan, berkelanjutan, berwawasan lingkungan, kemandirian, serta dengan menjaga keseimbangan kemajuan dan kesatuan ekonomi nasional."

Dari ketentuan di atas dapat dipahami bahwa terdapat prinsip-prinsip dalam mengelola alam dan lingkungan serta hubungannya dengan warga negara, antara lain yaitu:

1. Sumber daya alam mesti memberi manfaat untuk kemakmuran rakyat;

2. Demokrasi ekonomi, kebersamaan, keadilan, dan berwawasan ekologis.

Selanjutnya, aktivitas penambangan pasir, terutama di pesisir dan pantai, hendaknya didahului dan didasarkan pada izin prinsip dan analis dampak lingkungan (AMDAL), sebagaimana berdasarkan Pasal 262 ayat (1) Undang-Undang Republik Indonesia Nomor 9 Tahun 2015 tentang Perubahan Kedua Atas Undang-Undang Nomor 23 Tahun 2014 tentang Pemerintahan Daerah (selanjutnya disebut UU No. 9 Tahun 2015), mengatur bahwa:

"Rencana pembangunan Daerah ... dirumuskan secara transparan, responsif, efisien, efektif, akuntabel, partisipatif, terukur, berkeadilan, dan berwawasan lingkungan."

Berdasarkan Pasal 46 ayat (2) Peraturan Daerah Provinsi Sulawesi Selatan Nomor 2 Tahun 2019 tentang Rencana Zonasi Wilayah Pesisir dan Pulau-Pulau Kecil Provinsi Sulawesi Selatan Tahun 2019-2039 (selanjutnya disebut Perda Sulsel No. 2 Tahun 2019), mengatur bahwa: 
"Kegiatan yang boleh dilakukan di KPU-TB-P ... meliputi kegiatan pertambangan pasir laut wajib dilakukan studi kelayakan dan studi AMDAL atau UKL-UPL sesuai besaran usaha dan/atau kegiatan yang sesuai aturan perundangan."

Dari ketentuan di atas, dapat dipahami bahwa sejak perencanaan aktivitas penambangan pasir, harus ada keterlibatan masyarakat sekitar yang diperkirakan akan terkena dampak langsung maupun tidak langsung dari kebijakan tersebut (Y. Yudhistira., Wahyu Krisna Hidayat., \& Agus Hadiyarto, 2011).

Aktivitas penambangan pasir pada dasarnya dilakukan untuk memenuhi kebutuhan manusia di bidang infrastruktur baik untuk pemukiman maupun transportasi (Irfan Ido, 2019). Namun tidak dapat dipungkiri bahwa secara langsung maupun tidak langsung dapat berdampak pada kehidupan manusia dan lingkungan sekitarnya, baik kerusakan ekologi maupun ekonomi dan sosial budaya.

Kajian tentang aktivitas penambangan pasir bisa berdampak positif seiring dengan peningkatan kesejahteraan masyarakat setempat karena dapat memperoleh penghasilan tambahan (Muhammad Akbar., Zainal Said., \& R. Rusnaena, 2019), antara Rp. 400.000,00 - Rp. 1.000.000,00 per bulan. Penggalian pasir yang dilakukan secara individu atau kelompok menjadi sumber pendapatan baru karena dibeli langsung oleh pelaksana proyek. Begitu pula dengan perubahan cara produksi, yang awalnya masyarakat hanya mengandalkan hasil pertanian untuk memenuhi kebutuhan seharihari, malah beralih ke ekonomi industri melalui penambangan pasir yang langsung mengubah orientasi hidup secara drastis.

Selain berdampak positif baik secara ekonomi maupun sosial, penambangan pasir juga menimbulkan konflik horizontal akibat kerusakan ekologis. Kelompok masyarakat yang tanahnya terkena proyek pertambangan menjadi bagian dari pekerja tambang dan mendapatkan ganti rugi. Sedangkan kelompok yang tanahnya tidak terkena proyek pertambangan, selain tidak menerima kompensasi keuntungan dan pekerjaan penambangan, juga merasakan kerusakan lingkungan yang mengakibatkan konflik horizontal antara kedua belah pihak (Refki Hontong., Antonius Purwanto., \& Juliana Tumiwa, 2016). Sementara itu, konflik akibat aktivitas penambangan pasir juga tidak bisa dihindari antara masyarakat, pengembang, dan pemerintah. Diperlukan solusi, yaitu pendekatan yang tidak hanya ekologis tetapi juga sosial budaya (M. Sayful, 2019). Namun aktivitas penambangan pasir di wilayah pesisir pantai Galesong yang dilakukan atas kerja sama PT. Ciputra, PT. Yasmin, dan PT. Bengkalis sebagai operator lapangan sudah dilakukan sejak tahun 2017 di areal kurang dari 8 mil yang mengakibatkan terganggunya biota laut, terumbu karang, abrasi, dan tanaman mangrove. Selain itu, berdasarkan Pasal 46 ayat (3) huruf a Perda Sulsel No. 2 Tahun 2019, mengatur bahwa:

"Kegiatan yang tidak boleh dilakukan di KPU-TB-P ... meliputi melakukan penambangan kurang atau sama 8 mil laut diukur dari surut terendah." 
Selain itu, minimnya keterlibatan nelayan dan kelompok masyarakat di wilayah pesisir pantai Galesong, sehingga menimbulkan ketidakpuasan yang berakibat pada adanya perlawanan berupa demonstrasi yang mengganggu jalannya kegiatan penambangan pasir.

Telah banyak penelitian di Indonesia yang membahas tentang keberadaan tambang pasir, antara lain sebagai berikut.

Penelitian terkait analisis dampak kebijakan tambang pasir pada umumnya tentang dilibatkan masyarakat setempat sehinga meningkatkan ekonomi, dimana Yoga Fratama (2020) menyimpulkan bahwa:

"Dampak positif dari kegiatan pertambangan antara lain peluang kerja bagi masyarakat sekitar, peningkatan perekonomian, serta retribusi dan pajak yang dapat meningkatkan Pendapatan Asli Daerah. Adapun dampak negatifnya yaitu kerusakan lingkungan dan pencemaran, seperti debu, erosi, longsor dan bencana-bencana lainnya yang akan datang."

Desi Yunita et al. (2016) menyimpulkan bahwa:

"Masyarakat yang semula merupakan entitas dalam solidaritas mekanis, berangsur-angsur berubah menjadi masyarakat yang lebih organik, dengan ciri yang tampak pada keinginan suatu kelompok untuk menguasai aset produksi pasir besi. Fakta menunjukkan bahwa pelarangan aktivitas pertambangan telah meningkatkan aktivitas ilegalyang tidakterkendaliyang dampaknya sulit diukur. Upaya penyelamatan aset produksi harus diupayakan dengan mengambil alih pengelolaan sumber daya pasir besi dan membentuk badan ekonomi yang mewadahi, mengontrol, dan mendistribusikan hasil tambang oleh masyarakat tersebut, sehingga aktivitas penambangan pasir besi tersebut dapat dikendalikan."

Penelitian terkait tambang pasir yang mengakibatkan konflik horizontal, Rahmat Andi Wiyanto (2015) menyimpulkan bahwa:

"Keberadaan PT. Jogja Magasa Iron (PT. JMI) sebagai perusahaan tambang menuai respon pro dan kontra di kalangan masyarakat. Sehingga kehadiran konflik dalam penambangan pasir besi tidak bisa dihindari. Namun hal itu hanya bisa diminimalisir, terutama konflik horizontal antara masyarakat yang pro dengan masyarakat yang kontra dengan pihak kontra tambang."

Mohammad Kus Yunanto (2017) menyimpulkan bahwa:

"Konflik kebijakan penambangan pasir besi belum terselesaikan. hendaknya penyelesaian negosiasi harus dikembalikan pada orientasi terbaik, yaitu orientasi menang-menang (win-win), pendekatan hukum harus segera dilakukan, pendekatan sosial budaya adalah yang paling cocok, warga pesisir diikutkan dalam proyek penambangan pasir besi tersebut, serta komunikasi yang dua arah harus dilakukan."

Maria Maghdalena Diana Widiastuti., Godefridus Samderubun., \& Taslim Arifin (2018) menyimpulkan bahwa:

"Motivasi masyarakat dalam berjualan pasir dikarenakan motif ekonomi. Strategi yang diusulkan untuk solusinya adalah menetapkan harga pasir lokal dengan menginternalisasi biaya eksternalisasi, penegakan izin 
usaha pertambangan, dan membentuk kelompok peduli lingkungan pesisir untuk mengembangkan perekonomian masyarakat lokal. Eksternalisasi kegiatan penggalian pasir pantai harus dipertimbangkan oleh pemerintah karena akan berdampak pada kehidupan masyarakat pesisir dan seluruh masyarakat di Kabupaten Merauke. Tanpa mengurangi kebutuhan material untuk pembangunan daerah."

Fajriharish Nur Awan., B. Badaruddin., \& Miswar Budi Mulya. (2020) menyimpulkan bahwa:

"Penyebab terjadinya konflik sosial (resistensi) masyarakat terhadap penambangan pasir lautyang terjadi di Pantai Labu adalah perbedaan antar individu dalam hal pemahaman dan reaksi terhadap masalah, kepentingan terkait pelaku usaha yang mencari keuntungan dan masyarakat menuntut ganti rugi, perubahan sosial dalam hal musyawarah."

Dari beberapa uraian di atas, dapat dipahami bahwa penelitian terdahulu umumnya membahas tentang penambangan pasir yang melibatkan masyarakat setempat.

Adapun dalam penelitian iniakan membahas mengenai analisis kebijakan penambangan pasir laut yang beroperasi tanpa mengindahkan Pasal 33 ayat (3) dan ayat (4) UUD NRI Tahun 1945, UU No. 9 Tahun 2015, dan Perda Sulsel No. 2 Tahun 2019. Hal ini sangat jelas, karena aktivitas penambangan pasir di wilayah pesisir pantai Galesong kurang dari radius 8 mil yang diukur dari garis pantai (Aswan Sulfitra et al., 2019), sehingga mengakibatkan gangguan ekologis dan sosial ekonomi khususnya kelompok nelayan, serta menimbulkan konflik vertikal (kelompok nelayan dan perusahaan tambang pasir). Ada perbedaan yang jelas antara penelitian ini dengan penelitian terdahulu.

Berdasarkan uraian pendahuluan di atas, maka penelitian ini bertujuan untuk mengetahui landasan kebijakan dari aktivitas penambangan pasir di wilayah pesisir pantai Galesong. Selain itu, penelitian ini juga bertujuan untuk mengetahui dampak sosial dan ekonomi dari keberadaan tambang pasir terhadap masyarakat Galesong.

\section{METODE}

Penelitian ini dilakukan dalam bentuk "studi mikro demografi", yaitu jenis penelitian yang biasa disebut quasi anthropological (Singarimbun, 1986). Jenis penelitian ini juga merupakan upaya untuk menggabungkan penelitian kualitatif dengan penelitian kuantitatif. Namun bentuk analisisnya lebih menitikberatkan pada analisis kualitatif. Selain itu, metode penelitian kuantitatif berkontribusi lebih sebagai dukungan yang berfungsi untuk memberikan latar belakang yang terukur untuk mengkontekstualisasikan studi intensif skala kecil (Brannen, 1999).

Penelitian ini dilakukan di wilayah pesisir pantai Galesong, tepatnya di Desa Batu dan Sampulungan, Kecamatan Galesong Utara, dan Desa Beba, Kecamatan Galesong Selatan, Kabupaten Takalar, Provinsi Sulawesi Selatan. Lokasi ini dipilih karena pertama, lokasi tambang pasir berada di area tersebut; kedua, pekerjaan utama masyarakat setempat adalah nelayan; dan ketiga, abrasi terjadi di wilayah pesisir 
yang mengakibatkan kerusakan area pemakaman, rumah warga, sarana jalan dan tanggul. Informan dalam penelitian ini terdiri dari kepala dusun, kelompok nelayan kapal Jolloro, nelayan perahu ketinting, nelayan tangkap, nelayan jaring, serta anggota masyarakat bukan nelayan yang rumahnya terkena abrasi. Teknik penentuan informan dilakukan secara sengaja berdasarkan pengetahuan dan keterlibatan mereka dalam proses sosialisasi rencana tambang. Jumlah informan dalam penelitian ini sebanyak 14 orang yang sebagian besar adalah laki-laki, dan sebagian kecil adalah ibu rumah tangga (istri nelayan). Identitas informan tidak ditampilkan sebagai bagian dari kesepakatan penelitian. Penelitian ini mengusung azas confidential (kerahasiaan dan kenyamanan informan) untuk menghindari hal-hal yang dapat merugikan informan di kemudian hari.

Jenis data yang digunakan dalam penelitian ini, antara lain yaitu (Ismail Nurdin \& Sri Hartati, 2019):

1. Data Primer, adalah data yang bersumber dari hasil penelitian lapangan yang diperoleh melalui observasi dan wawancara; dan

2. Data Sekunder, adalah data referensi dan kepustakaan yang bersumber dari studi dokumen, buku, jurnal, artikel, dan media online.

Untuk memperoleh data yang dibutuhkan dalam penelitian ini, maka digunakan teknik pengumpulan data, yakni sebagai berikut:

1. Observasi, yakni dilakukan dengan cara melihat langsung aktivitas penambangan pasir di wilayah pesisir pantai Galesong, meliputi pantai tempat perahu ditambat, kegiatan nelayan, dan aktivitas masyarakat sekitar pantai;

2. Wawancara, yakni dilakukan dengan cara tanya jawab umum, kemudian dilanjutkan melalui pertanyaan-pertanyaan mendalam, diskusi, dan konfirmasi, baik secara perorangan maupun Focus Group Discussion (FGD); serta

3. Studi dokumen, yakni dilakukan dengan cara memilih secara khusus dan difokuskan pada Pasal 33 ayat (3) dan ayat (4) UUD NRI Tahun 1945, UU No. 9 Tahun 2015, dan Perda Sulsel No. 2 Tahun 2019 yang berhubungan dengan aktivitas penambangan pasir.

Sebagai pelengkap teknik pengumpulan data di atas, maka hasil observasi dan wawancara kemudian didokumentasikan.

Analisis data dalam penelitian ini dilakukan secara kualitatif dalam arti bahwa penarikan pernyataan-pernyataan dengan menghubung-hubungkan dari berbagai aspek yang ada. Kemudian pada gilirannya, makna tersebut akan ditarik pada tingkat tertinggi. Hasil analisis ini akan diintegrasikan dalam bentuk deskriptif-interpretatif dan reflektif, sehingga dapat terjamin kredibilitas, dependabilitas, dan objektivitas penelitian ini terjamin. 


\section{HASIL DAN PEMBAHASAN}

\section{A. Kebijakan Pemerintah dan Aktivitas Penambangan Pasir di Wilayah Pesisir Pantai Galesong}

Aktivitas penambangan pasir di wilayah pesisir pantai Galesong adalah untuk reklamasi CPI dan NPM. Pasir di wilayah pesisir pantai Galesong yang merupakan sedimen yang terbawa arus ke laut, yang merupakan anugerah yang harus dimanfaatkan, dan tentunya harus berdasarkan prosedur pemanfaatan sumber daya wilayah pesisir berdasarkan Undang-Undang serta peraturan yang terkait (Andi Sri Rezky Wulandari \& Makkah H. M., 2019), antara lain Undang-Undang Republik Indonesia Nomor 1 Tahun 2014 tentang Perubahan Atas Undang-Undang Nomor 27 Tahun 2007 tentang Pengelolaan Wilayah Pesisir dan Pulau-Pulau Kecil (selanjutnya disebut UU No. 1 Tahun 2014).

Aktivitas penambangan pasir di wilayah pesisir pantai dan laut, sebagaimana berdasarkan Pasal 51 ayat (1) huruf a UU No. 1 Tahun 2014, mengatur bahwa:

"Menteri berwenang menerbitkan dan mencabut izin pemanfaatan pulaupulau kecil dan pemanfaatan perairan di sekitarnya yang menimbulkan Dampak Penting dan Cakupanyang Luas serta Bernilai Strategis terhadap perubahan lingkungan."

Berdasarkan Pasal 14 UU No. 9 Tahun 2015, mengatur bahwa:

"Penyelenggaraan Urusan Pemerintahan bidang kehutanan, kelautan, serta energi dan sumber daya mineral dibagi antara Pemerintah Pusat dan Daerah Provinsi."

Berdasarkan Pasal 350 UU No. 9 Tahun 2015, mengatur bahwa "Kepala daerah wajib memberikan pelayanan perizinan sesuai dengan ketentuan peraturan perundang-undangan".

Dari ketentuan di atas, dapat diartikan bahwa segala macam hal yang berkaitan dengan pertambangan, baik yang terkait dengan penetapan izin kuasa pertambangan, kontrak karya, perjanjian karya pengusahaan pertambangan batubara, maupun lainnya, ditangani oleh pejabat yang berwenang memberikan izin dalam hal ini adalah Menteri Energi dan Sumber Daya Mineral dan Pemerintah Daerah Provinsi.

Aktivitas penambangan pasir di wilayah pesisir pantai Galesong telah dimulai sejak tahun 2017, sedangkan Perda Sulsel No. 2 Tahun 2019 ditetapkan oleh Gubernur tanggal 8 Mei 2019. Artinya, aktivitas penambangan pasir di wilayah pesisir pantai Galesong pada tahun 2017-2018 belum mengacu pada Perda Sulsel No. 2 Tahun 2019 yang seharusnya menjadi acuan dalam pemberian izin lokasi dan izin pengelolaan pertambangan pasir.

Berdasarkan data lapangan, aktivitas penambangan pasir dilakukan kurang dari 8 mil laut dari sudut terendah, serta mereka melakukan aktivitas penambangan pasir di tempat pemijahan alami biota laut, yang sebelum menjadi tempat nelayan kecil 
dan tradisional melakukan penangkapan ikan untuk kebutuhan sehari-harinya. Olehnya itu, aktivitas penambangan pasir di wilayah pesisir pantai Galesong dinilai menyimpang dan bertentangan dengan pemberian izin aktifitas, sebagaimana berdasarkan Pasal 17 ayat (2) UU No. 1 Tahun 2014, mengatur bahwa:

"Pemberian Izin Lokasi ... wajib mempertimbangkan kelestarian Ekosistem pesisir dan pulau-pulau kecil, Masyarakat, nelayan tradisional, kepentingan nasional, dan hak lintas damai bagi kapal asing."

\section{B. Dampak Aktivitas Penambangan Pasir terhadap Kondisi Sosial Ekonomi Masyarakat di Wilayah Pesisir Pantai Galesong}

\section{Hilangnya Area Tangkapan (Fishing Ground)}

Menurut para nelayan, aktivitas penambangan pasir di wilayah pesisir pantai Galesong adalah tempat mereka menangkap ikan, cumi-cumi, kepiting dan juga meletakkan sejumlah rompong (alat bantu penangkapan ikan). Beberapa bebatuan diyakini sebagai rumah ikan, cumi-cumi, dan kepiting, serta ikan pari hidup dan berkembang biak di kawasan itu. Mereka menyebutnya dengan berbagai macam istilah, antara lain Bone Pama, Bone Pute, Bone Luara, dan Coponga.

Namun, sejak aktivitas penambangan pasir di wilayah pesisir pantai Galesong yang dilakukan oleh kapal-kapal besar mulai dari pagi, siang, dan malam, mereka telah menyedot semua pasir beserta bebatuan dan terumbu karang yang menjadi rumah bagi ikan, cumi-cumi, dan kepiting. Semua tersedot ke dalam kapal dengan teknologi canggih dengan kapasitas hisap yang besar. Aktivitas penambangan pasir di wilayah pesisir pantai Galesong hanya akan berhenti jika kerukan pasir laut sudah mencapai lapisan tanah lumpur yang kedalamannya minimal 10 meter ke bawah dan kemungkinan lebih dalam lagi sesuai kandungan ketersediaan pasir di tempat kerukan. Selama masih ada pasir laut di area tambang, maka kapal penambang akan terus melakukan proses kerukan hingga mencapai dasar tanah lumpur.

Secara umum, aktivitas penambangan pasir laut menyebabkan air menjadi keruh. Ini karena lapisan pasir paling bawah adalah tanah yang berlumpur. Oleh karena itu, pada saat pengerukan mencapai dasar, maka akan menyebabkan air menjadi keruh. Kondisi tersebut membuat nelayan tidak dapat menangkap hasil laut di wilayah tersebut sejak dilakukan pengerukan. Nelayan kecil yang menangkap di daerah tersebut harus membalik haluan dan mencari tempat penangkapan lain di tempat yang lebih jauh.

Hal ini diperkuat pula dengan wawancara langsung dengan banyak informan nelayan yang menyatakan bahwa nelayan harus menaikkan biaya operasional bahan bakar hingga 20 liter untuk pindah ke daerah penangkapan baru. Oleh karena itu, aktivitas penambangan pasir di wilayah pesisir pantai Galesong 
yang ditujukan untuk reklamasi berdampak signifikan terhadap kegiatan pelabuhan perikanan dan daerah penangkapan ikan. Berikut penuturannya:

"Di daerah ini (pesisir), kami biasa menangkap ikan. Sekarang ini sudah sangat sulit. Nyatanya, tidak ada lagi yang bisa ditangkap. Itu sebabnya kami harus pergi ke laut yang jauh. Jika tidak, tidak ada ikan yang bisa didapat."

\section{Perubahan Sosial Ekonomi Nelayan}

Daeng Junjung adalah seorang nelayan Galesong berusia 46 tahun. Setiap hari dia menjadi nelayan dengan menggunakan alat tangkap jaring dan pancing. Pada saat melaut, ia hanya membutuhkan waktu mulai 12 hingga 24 jam, dengan menggunakan perahu kecil bernama jolloro. Jarak melautnya antara 1 mil hingga 10 mil dari wilayah pesisir laut Sampulungan.

Daeng Senja adalah seorang nelayan dusun Sampulungan berusia 45 tahun. Setiap hari dia menjadi nelayan dengan menggunakan alat tangkap pancing. Pada saat melaut, ia hanya membutuhkan waktu mulai 20 hingga 24 jam, dengan menggunakan jolloro. Jarak melautnya antara 1 mil hingga 8 mil dari wilayah pesisir pantai Galesong.

Ia merupakan nelayan pemancing di dusun Sampulungan. Ketika bekerja sebagai nelayan, rata-rata ia membutuhkan waktu operasi sekitar 20 hingga 24 jam dengan menggunakan perahu jenis jolloro. Daeng Senja beroperasi sebagai nelayan pada kejauhan 1-8 mil dari garis pantai. Dengan area tangkap yang relatif tidak begitu jauh, yaitu di sekitar wilayah pesisir laut. Nelayan hanya menangkap ikan-ikan kecil seperti ikan merah kecil dan ikan katombo.

Akan tetapi, setelah adanya aktivitas penambangan pasir di wilayah pesisir pantai Galesong, Daeng Senja dan nelayan kecil lainnya harus kehilangan wilayah penangkapannya. Agar tidak terus menerus menderita, ia kemudian memilih untuk bergabung bersama dengan para nelayan penangkap ikan di laut dalam yang biasanya melaut sekitar 15 hari. Mereka menjadi sawi pada punggawa perahu-perahu besar. Hal ini harus mereka lakukan untuk memenuhi kebutuhan keluarganya agar tetap bisa bertahan hidup.

Selain aktifitas menangkap ikan, perubahan drastis juga dialami oleh nelayan penangkap kepiting. Sebelum aktivitas penambangan pasir, para nelayan akan meletakkan rakkang (alat tangkap perangkap kepiting) miliknya berdampingan dengan rakkang milik nelayan lainnya. Namun setelah beroperasinya aktivitas penambangan pasir, para nelayan kemudian berkompetisi dan mengakibatkan perebutan lahan hingga saling merusak rakkang. Selain itu, tidak jarang di antara para nelayan harus kehilangan rakkang mereka.

Adapun aktivitas nelayan yang juga merupakan pembudidaya rumput laut mengalami kondisi yang memprihatinkan. Sekitar tahun 2018 hingga saat ini, 
nelayan rumput laut tidak dapat lagi memperoleh hasil dari laut karena benih yang mereka tanam tidak dapat tumbuh dengan baik. Kondisi air laut yang keruh terjadi karena pasir di sekitar hamparan rumput laut diambil secara besarbesaran menggunakan kapal dengan daya hisap pasir yang sangat besar. Nelayan meyakini hal ini berdampak signifikan terhadap pertumbuhan benih rumput laut yang dibentangkan. Kegagalan tanaman rumput laut menyebabkan petani merugi.

\section{Simalakama Keberadaan Patroli Polisi Laut}

Sejak adanya aktivitas penambangan pasir, secara tiba-tiba patroli polisi laut cukup intens beraktifitas di wilayah pesisir pantai Galesong. Saat polisi laut melintasi wilayah pesisir pantai Galesong, para nelayan yang kedapatan akan diperiksa. Kenyataannya, polisi laut melakukan pemeriksaan surat kapal dengan sangat ketat dan rumit.

Menurut beberapa nelayan, saat ini biaya pengurusan dokumen kapal sangat mahal, yakni sekitar 3 juta hingga 9 juta rupiah. Selain itu, proses pengerjaan dokumen yang dianggap memakan waktu cukup lama dan harus menunggu berbulan-bulan hingga suratnya diterbitkan. Hal ini membuat para nelayan enggan (malas) untuk mengurus dokumen kapal, sementara polisi laut selalu mengawasi rute perjalanan menuju wilayah tangkapan para nelayan.

Saat polisi patroli laut menangkap nelayan, polisi harus meminta surat-surat kapal. Polisi laut tidak mau berkompromi dengan nelayan. Jika nelayan tidak memiliki surat-surat, maka mereka tidak akan diizinkan untuk berlayar. Hal yang sama juga terjadi pada nelayan yang telah memiliki surat keterangan pengurusan izin kapal. Nelayan tetap dilarang melaut, meski sudah menunjukkan surat keterangan sedang dalam proses pengurusan administrasi.

Dalam banyak kasus, nelayan mengakui bahwa kapal yang ditemukan tidak memiliki izin berlayar akan ditangkap dan dibawa ke pantai oleh polisi laut. Kapal-kapal tersebut ditahan dan hanya diperbolehkan berlayar jika mereka mampu membayar sejumlah uang yang bagi para nelayan merupakan "uang tilang" sebesar 1 hingga 2 juta rupiah. Jumlah yang sangat besar bagi para nelayan Sampulungan. Padahal hasil tangkapan mereka belum tentu banyak, dan sangat tergantung pada keberuntungannya dalam melaut. Hasil dari melaut juga harus dibagi dengan nelayan lain dan punggawa, yang merupakan bos mereka. Kondisi ini membuat nelayan merasa tertekan, dan tidak lagi leluasa melaut seperti dulu. Kondisi ini tentu saja membuat para nelayan semakin terpuruk dalam hal pendapatan hasil melaut.

\section{Gejolak Penolakan Masyarakat}

Pertemuan antara pihak perusahaan dengan masyarakat Sampulungan pertama kali diprakarsai oleh Dinas Perikanan dan Kelautan serta Pemerintah 
Pusat pada tahun 2017. Pertemuan tersebut merupakan sosialisasi yang dilakukan oleh para penambang pasir yang menyampaikan kepada masyarakat bahwa akan dilakukan aktivitas penambangan pasir di wilayah pesisir pantai Galesong. Oleh karena itu, pertemuan tersebut bukanlah proses mendengarkan aspirasi warga dan mencari persetujuan mereka. Tentunya pertemuan tersebut menuai kritik dan penolakan ketidaksetujuan dari seluruh warga yang hadir pada pertemuan sosialisasi tersebut. Meski begitu, penolakan tersebut tidak berpengaruh dan sia-sia saja.

Masyarakat menilai pertemuan tersebut hanya sebagai sarana menenangkan warga, selain sebagai bentuk formalitas pemberitahuan kepada warga masyarakat di wilayah pesisir pantai Galesong. Faktanya, meskipun 100 persen warga yang hadir dalam pertemuan tidak setuju, akan tetapi aktivitas penambangan pasir tetap akan dilakukan karena dinilai sudah mengantongi banyak dokumen pendukung izin pertambangan.

Menurut Kepala Dusun Sampulungan Lompo, bahwa:

"Pertemuan tersebut menyosialisasikan sosialisasi bahwa akan dilakukan aktivitas penambangan pasir. Perusahaan sudah mengemukakan dampak yang akan terjadi, yaitu salah satunya adalah kemungkinan terjadi abrasi. Akan tetapi, mereka juga berpendapat bahwa penyebab abrasi tidak hanya karena aktivitas penambangan pasir, tetapi bisa juga karena hal lain, seperti ombak besar dan lain-lain. Namun karena salah satu penyebabnya adalah aktivitas penambangan pasir, pihak perusahaan tetap akan memberikan ganti rugi kepada masyarakat jika terjadi abrasi proses penambangan pasir."

Lebih lanjut, Kepala Dusun Sampulungan Lompo menyatakan bahwa:

"Pihak perusahaan juga menyampaikan bahwa kerugian lainnya yang dialami para nelayan yang dianggap telah mengurangi hasil tangkapan karena aktivitas penambangan pasirjuga akan diberiganti rugi yang sepadan. Meski sudah dijanjikan ganti rugi, masyarakat nelayan tetap menolak diadakannya aktivitas penambangan pasir. Hanya saja, karena pihak pemerintah dianggap terlanjur telah memberikan izin, maka aktivitas penambangan pasir di wilayah pesisir pantai Galesong tetap dilakukan."

Pada pertemuan yang dilakukan di tingkat provinsi, keterlibatan masyarakat juga tidak memenuhi perwakilan masyarakat. Pasalnya, beberapa nama yang diundang dalam rapat tersebut dinilai tidak mewakili warga. Beberapa nama yang sebelumnya menghadiri pertemuan sosialisasi dan menyatakan ketidaksetujuan tidak diundang, dan namanya telah diganti menjadi tokoh masyarakat lainnya.

Saat itu, tokoh masyarakat yang sempat hadir dalam sosialisasi berharap untuk diundang kembali guna membahas aktivitas penambangan pasir. Namun, 
selama menunggu, mereka tidak pernah mendapat undangan lagi. Hal ini membuat warga percaya dan beranggapan bahwa aktivitas penambangan pasir dibatalkan. Barulah di kemudian hari mereka mengetahui bahwa rapat telah dilaksanakan dan banyak nama telah diubah menjadi nama tokoh masyarakat lainnya, dan tidak diketahui mewakili dusun apa.

Secara umum, pada tahun 2019 telah terjadi abrasi di beberapa tempat di daerah pesisir Takalar dan sekitarnya. Penyebabnya diduga kuat berasal dari aktivitas penambangan pasir di wilayah pesisir pantai Galesong. Sejak perencanaan aktivitas penambangan pasir hingga penelitian ini dilakukan, masyarakat nelayan terus melakukan protes terhadap aktivitas penambangan pasir di wilayah pesisir pantai Galesong dan pulau-pulau kecil. Tetapi aktivitas penambangan pasir terus berlanjut.

Menurut masyarakat Sampulungan, kerugian yang dialami masyarakat antara lain banyaknya rumah roboh yang belum mendapatkan ganti rugi. Bantuan yang datang kepada warga terdampak dinilai tidak sebanding dengan kerugian yang mereka terima. Informasi peneliti terkait hal ini adalah tidak ada bantuan ganti rugi dari penambang karena menurut mereka nelayan di wilayah pesisir pantai Galesong sudah tidak kooperatif dan tidak mau bekerjasama dengan perusahaan.

Hal ini terjadi karena dalam kurun waktu berjalannya aktivitas penambangan pasir di wilayah pesisir pantai Galesong, warga masyarakat secara intensif melakukan protes dan melakukan berbagai tindakan yang dinilai merugikan perusahaan tambang. Oleh karena itu, pihak perusahaan beralasan bahwa dana yang tadinya akan digunakan untuk memberikan ganti rugi, kini digunakan untuk membiayai keamanan dari berbagai tindakan yang dilakukan oleh warga di wilayah pesisir pantai Galesong, termasuk "menyewa" pihak-pihak tertentu untuk mengamankan wilayah aktivitas penambangan pasir.

\section{KESIMPULAN DAN SARAN}

Berdasarkan uraian hasil dan pembahasan, maka dapat disimpulkan bahwa aktivitas penambangan pasir di wilayah pesisir pantai Galesong dimulai pada Tahun 2017 sedangkan Perda Sulsel No. 2 Tahun 2019 ditetapkan oleh Gubernur pada tanggal 8 Mei 2019. Artinya bahwa aktivitas penambangan pasir di wilayah pesisir pantai Galesong pada Tahun 2017-2018 belum mengacu pada Perda Sulsel No. 2 Tahun 2019, yang seharusnya menjadi acuan untuk mengeluarkan izin lokasi dan izin pengelolaan pertambangan pasir. Adapun dampak dari aktivitas penambangan pasir terhadap kondisi sosial ekonomi masyarakat di wilayah pesisir pantai Galesong, antara lain hilangnya wilayah penangkapan ikan akibat pengerukan pasir laut, menyebabkan air menjadi keruh. Selain itu, terjadi perubahan sosial ekonomi, dimana para nelayan kecil harus meninggalkan aktifitasnya dan bergabung dengan para nelayan penangkap 
ikan di laut dalam dan menjadi sawi pada punggawa perahu-perahu besar. Dampak selanjutnya adalah adanya patroli polisi laut yang membuat para nelayan merasa tertekan dan tidak lagi memiliki kebebasan untuk melaut seperti dulu kala. Olehnya itu, sejak direncanakannya aktivitas penambangan pasir sejak perencanaan kegiatan penambangan pasir hingga penelitian ini dilakukan, masyarakat nelayan terus melakukan protes terhadap aktivitas penambangan pasir di wilayah pesisir pantai Galesong dan pulau-pulau kecil. Namun, aktivitas penambangan pasir terus berlanjut. Berdasarkan kesimpulan tersebut, dampak sosial ekonomi warga dan kerugian lingkungan mengharuskan banyak pihak dan stakeholder untuk memberikan perhatian serius terhadap masalah ini. Oleh karena itu, Pemerintah Daerah perlu membuat model kebijakan dalam pengelolaan aktivitas penambangan pasir di wilayah pesisir pantai Galesong. Jika tidak, cepat atau lambat masalahnya akan semakin membesar.

\section{REFERENSI}

Andi Sri Rezky Wulandari \& Makkah H. M. (2019). Tinjauan Yuridis Reklamasi Pantai dan Implikasinya di Anjungan Pantai Losari Makassar. Petitum, Universitas Indonesia Timur, 7(1), hlm. 59-80.

Aswan Sulfitra, et al. (2019). Catatan Akhir Tahun 2019 Walhi Sulsel: Degradasi Lingkungan \& Bencana Ekologis di Sulawesi Selatan. Makassar: Wahana Lingkungan Hidup Indonesia (Walhi) Daerah Sulawesi Selatan.

Desi Yunita, et al. (2016). Eksploitasi Pasir Besi dan Dampak Lingkungan Sosial, Budaya, Ekonomi pada Masyarakat di Pesisir Pantai Selatan Jawa Barat. Sosioglobal: Jurnal Pemikiran dan Penelitian Sosiologi, Universitas Padjadjaran, 1(1), hlm. 1432. doi: https://doi.org/10.24198/jsg.v1i1.11183

Fajriharish Nur Awan., B. Badaruddin., \& Miswar Budi Mulya. (2020). Faktor Penyebab Konflik Sosial Masyarakat Pesisir Penambangan Pasir Laut di Pantai Labu Kabupaten Deli Serdang. Jurnal Niara, Universitas Lancang Kuning, 13(1), hlm. 252-259. doi: https://doi.org/10.31849/niara.v13i1.4294

Irfan Ido. (2019). Dampak Usaha Kegiatan Penambangan Pasir terhadap Perubahan Mata Pencaharian di Kabupaten Muna Barat. Journal Publicuho, Universitas Halu Oleo, 2(1), hlm. 30-37. doi: http://dx.doi.org/10.35817/jpu.v2i1.5941

Ismar Hi Garuan \& S. Suranto. (2016). Evaluasi Program Penataan Kawasan Pesisir Kota Ternate (Studi Kasus Program Reklamasi Pantai Halmahera 2014). Journal of Governance and Public Policy, Universitas Muhammadiyah Yogyakarta, 3(1), hlm. 62-93. doi: http://dx.doi.org/10.18196/jgpp.2016.0051

M. Sayful. (2019). Interaksi Sosial dan Reproduksi Nilai Budaya Masyarakat Nelayan di Pelabuhan Paotere Kota Makassar. Sosioreligius: Jurnal Ilmiah Sosiologi Agama, Universitas Islam Negeri Alauddin Makassar, 4(2), hlm. 42-60.

Maria Maghdalena Diana Widiastuti., Godefridus Samderubun., \& Taslim Arifin. (2018). Strategi Kebijakan Penanggulangan Penggalian Pasir Pantai di Pantai Nasai Kabupaten Merauke. Jurnal Kebijakan Sosial Ekonomi Kelautan dan Perikanan, Kementerian Kelautan dan Perikanan RI, 8(1), hlm. 27-38. doi: http://dx.doi. org/10.15578/jksekp.v8i1.6850 
Mohammad Kus Yunanto. (2017). Analisis Resolusi yang Tepat terhadap Konflik Kebijakan Penambangan Pasir Besi di Pesisir Selatan Kabupaten Kulon ProGo Provinsi D.I. Yogyakarta. Paradigma: Jurnal Ilmu Administrasi, Sekolah Tinggi Ilmu Administrasi AAN, 6(1), hlm. 87-106.

Muhammad Akbar., Zainal Said., \& R. Rusnaena. (2019). Implikasi Penambangan Pasir dalam Meningkatkan Perekonomian Masyarakat Padaidi Kab. Pinrang. Banco: Jurnal Manajemen dan Perbankan Syariah, Institut Agama Islam Negeri Parepare, 1(2), hlm. 59-69. doi: https://doi.org/10.35905/banco.v1i2.1304

Peraturan Daerah Provinsi Sulawesi Selatan Nomor 2 Tahun 2019 tentang Rencana Zonasi Wilayah Pesisir dan Pulau-Pulau Kecil Provinsi Sulawesi Selatan Tahun 2019-2039. (Lembaran Daerah Provinsi Sulawesi Selatan Tahun 2019 Nomor 2).

Peraturan Pemerintah Pengganti Undang-Undang Republik Indonesia Nomor 2 Tahun 2014 tentang Perubahan Atas Undang-Undang Nomor 23 Tahun 2014 tentang Pemerintahan Daerah. (Lembaran Negara Republik Indonesia Tahun 2014 Nomor 246. Tambahan Lembaran Negara Republik Indonesia Nomor 5589).

Rahmat Andi Wiyanto. (2015). "Konflik Penambangan Pasir Besi di Desa Garongan Kecamatan Panjatan Kabupaten Kulon Progo". Skripsi. Fakultas Ilmu Sosial dan Humaniora Universitas Islam Negeri Sunan Kalijaga, Yogyakarta.

Refki Hontong., Antonius Purwanto., \& Juliana Tumiwa. (2016). Konflik Sosial dalam Aktifitas Tambang Galian C di Desa Tateli Tiga. Acta Diurna Komunikasi, Universitas Sam Ratulangi, 5(5), hlm. 1-14.

S. Sartono. (2019). Kebijakan Pengembangan Infrastruktur Transportasi Laut pada Dinas Perhubungan Kabupaten Muna Barat. Journal Publicuho, Universitas Halu Oleo, 2(2), hlm. 84-98. doi: http://dx.doi.org/10.35817/jpu.v2i2.8377

Undang-Undang Dasar Negara Republik Indonesia Tahun 1945.

Undang-Undang Republik Indonesia Nomor 27 Tahun 2007 tentang Pengelolaan Wilayah Pesisir dan Pulau-Pulau Kecil. (Lembaran Negara Republik Indonesia Tahun 2007 Nomor 84. Tambahan Lembaran Negara Republik Indonesia Nomor 4739).

Undang-Undang Republik Indonesia Nomor 1 Tahun 2014 tentang Perubahan Atas Undang-Undang Nomor 27 Tahun 2007 tentang Pengelolaan Wilayah Pesisir dan Pulau-Pulau Kecil. (Lembaran Negara Republik Indonesia Tahun 2014 Nomor 2. Tambahan Lembaran Negara Republik Indonesia Nomor 5490).

Undang-Undang Republik Indonesia Nomor 23 Tahun 2014 tentang Pemerintahan Daerah. (Lembaran Negara Republik Indonesia Tahun 2014 Nomor 244. Tambahan Lembaran Negara Republik Indonesia Nomor 5587).

Undang-Undang Republik Indonesia Nomor 2 Tahun 2015 tentang Penetapan Peraturan Pemerintah Pengganti Undang-Undang Nomor 2 Tahun 2014 tentang Perubahan Atas Undang-Undang Nomor 23 Tahun 2014 tentang Pemerintahan Daerah. (Lembaran Negara Republik Indonesia Tahun 2015 Nomor 24. Tambahan Lembaran Negara Republik Indonesia Nomor 5657). 
Undang-Undang Republik Indonesia Nomor 9 Tahun 2015 tentang Perubahan Kedua Atas Undang-Undang Nomor 23 Tahun 2014 tentang Pemerintahan Daerah. (Lembaran Negara Republik Indonesia Tahun 2015 Nomor 58. Tambahan Lembaran Negara Republik Indonesia Nomor 5679).

Y. Yudhistira., Wahyu Krisna Hidayat., \& Agus Hadiyarto. (2011). Kajian Dampak Kerusakan Lingkungan Akibat Kegiatan Penambangan Pasir di Desa Keningar Daerah Kawasan Gunung Merapi. Jurnal Ilmu Lingkungan, Universitas Diponegoro, 9(2), hlm. 76-84. doi: https://doi.org/10.14710/jil.9.2.76-84

Yoga Fratama. (2020). “Upaya Pemerintah dalam Menanggulangi Dampak Galian Tambang Type C (Studi Kecamatan Sekernan Kabupaten Muaro Jambi)". Skripsi. Fakultas Syariah, Universitas Islam Negeri Sulthan Thaha Saifuddin, Jambi.

I Dewi Anggariani., Santri Sahar., \& M. Syaiful. (2020). Tambang Pasir dan Dampak I Sosial Ekonomi Masyarakat di Pesisir Pantai. SIGn Journal of Social Science, CV. Social ' I Politic Genius (SIGn), 1(1), hlm. 15-29. doi: https://doi.org/10.37276/sjss.v1i1.96

ᄂ _ _ _ _ _ _ _ _ _ _ _ _ _ _ _ _ _ _ _ _ _ _ _ _ _ _ _ _ _ _ _ . 